\title{
Research on Russia Participation in the Regional Cooperation in Northeast Asia in the Context of Digital Economy
}

\author{
Cao Zhihong ${ }^{1, *}$ \\ ${ }^{1}$ Institute of Northeast Asian Studies of Heilongjiang Provincial Academy of Social Sciences, Harbin, 150028, \\ China. \\ *Email:13845007400@163.com
}

\begin{abstract}
This paper analyzes the current situation of Russia's participation in regional cooperation in Northeast Asia and the constraints of expanding regional cooperation with other countries in the region. In the context of digital economy, the paper expounds the path choice for Russia to break through the western containment, seek the technology and market of the East, create new economic growth point of domestic social development, and deepen the regional cooperation with northeast Asian countries. It concludes that Russia-US relations continue to deteriorate due to sanctions, information warfare and other issues. Based on the judgment that it is difficult for Russia and the West to turn the corner in the short term, Russia will further deepen its regional cooperation with northeast Asian countries in 2021. This study belongs to the category of international relations. On the basis of drawing lessons from the theories of international relations and diplomacy, quantitative research method is used for quantitative analysis, and regional and categorical difference analysis is carried out by comparative research method
\end{abstract}

Keywords: Northeast Asia, Regional Cooperation, Russia, Digital Economy.

\section{INTRODUCTION}

As early as 2011, Russian Presidential adviser Vladimir Graziyev proposed that information and communication would be one of the core technologies of the sixth new technological approach, and he expected Russia to make some efforts in this field and take advantage of the new wave of accelerated global economic growth before the overall structural reform of the world economy. However, the digitalization degree of manufacturing, management and transaction mode in Russia is relatively low. The lack of digitalization of enterprises is one of the important reasons that Russia's labor productivity is lower than that of leading industrial countries. In 2017, The Russian Federation issued two documents, the "Digital Economy Plan of the Russian Federation" and the "Development Strategy for the Russian Information Society (2017-2030)", indicating the urgency of promoting digital development in Russia. As a result,
Russia must want to work with countries that are making a difference in the digital sphere.

In 2020, due to sanctions, information warfare, NATO and other issues, there was no significant easing on Russia-US relations. In order to break through the Western containment and strive for a greater voice in Northeast Asia, Russia will shift its strategic focus to the east and actively "look east" to seize opportunities through searching for technology and markets in the East to further deepen cooperation with Northeast Asian countries in the fields of politics, economy, trade, and security, and create new economic growth points for domestic social development. Based on the judgment that Russia and the West are difficult to turn around in the short term, we believe that Russia will further deepen regional cooperation with Northeast Asian countries in 2020. 


\section{RESEARCH METHODS}

In this paper, the interdisciplinary research method, quantitative and qualitative analysis research method are comprehensively used for empirical analysis. From the perspective of regional economics and development economics, this paper analyzes the theoretical basis, policy measures, industrial cohesion, security cooperation and implementation effects of Russia's participation in northeast Asia regional cooperation under the background of digital economy from multiple angles and directions. By collecting and sorting out a large number of literature and relevant data, especially the latest research results on relevant topics in the Russian academic circle and the authoritative data of the Russian Federal Statistics Bureau, the paper systematically sorted out the status quo of Russia's participation in the regional cooperation in Northeast Asia, as well as a number of unfavorable factors restricting the cooperation. Thus, the evolution trend of political, economic and security cooperation between Russia and other countries in the region in 2021 is summarized. The application of quantitative and qualitative analysis makes research object of this article more systematic, scientific and accurate.

\section{STATUS OF COOPERATION BETWEEN RUSSIA AND NORTHEAST ASIAN COUNTRIES}

First, Sino-Russian political relations have deepened in an all-round way. Since 2018, Russia has continued it stable political contacts with all Northeast Asian countries. The major changes in the international landscape have been most vividly reflected as of 2019. In this uncertain world, SinoRussian relations are viewed as the "predictable factors". In 2018, Xi Jinping and Putin held four major meetings. In 2017, Russia's "Social Public Opinion Foundation" research report showed that $62 \%$ of Russians believe that China is Russia's most "close and friendly" country. From December 2017 to February 2018, the United States successively issued the "National Security Strategy Report", "National Defense Strategy Report" and "Strategic Nuclear Posture" reports, in three of which Russia and China were characterized as American "strategic competitors". China and Russia are getting closer today to form the "partnership but no alliance" as a result of the external squeeze from the United States. Russia-Japan political relations have further eased. For a long time, Japan has continuously promoted Russia's Far East region development and integration into AsiaPacific economic circle with highly developed original technology and strong financial support. Japan is also becoming the most crucial part of Russia's AsiaPacific layout. In recent years, the two sides have overcome obstacles and strengthened their willingness to deepen regional multilateral cooperation. In 2018, the heads of state of Russia and Japan held four meetings, and their mutual understanding and trust reached a new level in recent years. The political relations between Russia and South Korea have been obviously strengthened. Russia-Korea relations have been placed by Russia as a priority in its Asia-Pacific political and diplomatic strategy. On June 21-23, 2018, South Korean President Moon Jae-In visited Russia, the two sides discussed the regional economic and trade cooperation and the common concerns between the two countries in a series of international issues, negotiated the joint statement of the Russian Federation and the Republic of Korea, signed the cooperation agreements, and issued a joint statement after the meeting, which reflected the priority in the Russia-Korea relations aiming to maximize the potential of cooperation and improve the efficiency of cooperation, especially in the field of innovation to find a new direction for pragmatic interaction.[1]Russia-Mongolia political relations have gradually become closer. In 2017, after Battugal succeeded Mongolian President, Russia-Mongolia relations have been further strengthened on the former solid base. From May 6th to 17th, 2018, Mongolian Ministry of Foreign Affairs Damdin Zogbart visited Russia. At the summit of the Qingdao Cooperation Organization in Qingdao, China, on June 9, 2018, President Putin and President Battugal met and discussed multi-field cooperation between the two countries [2].

Second, economic and trade cooperation with Northeast Asian countries continues to progress. The scale and quality of Sino-Russian trade have both improved. After Trump took office, U.S. unilateralism and protectionist policies gained ground and Sino-U.S. trade frictions further escalated in 2018. After the Ukrainian crisis, U.S. economic sanctions on Russia will continue to 2024. As both China and Russia have been strategically squeezed from the United States, China and Russia have a stronger desire and motivation to strengthen pragmatic cooperation in various fields. In terms of trade, in 2018, the bilateral trade volume between China and Russia exceeded the 100 billion US dollar mark for the first time. According to statistics from the General Administration of Customs of China, the bilateral trade volume between China and Russia was 107.056 billion US dollars in 2018, an increase of $27.1 \%$ yearon-year, which was higher than $20.8 \%$ in 2017 . As of 
the year, China continued to maintain its status as Russia's largest trading partner.[3] In terms of practical cooperation, China's Ministry of Commerce and Russia's Ministry of Economic Development signed the "Memorandum of Understanding on Promoting High-quality Development of Bilateral Trade" in 2019, which made agriculture, science and technology and digital economy the key areas for innovative development of bilateral economic and trade. The growth point of China-Russia cooperation will no longer be the traditional field of energy and resources, but the high-tech and digital economy with the characteristics of the times. Russia-Japan trade has gradually strengthened. Japan is Russia's tenth largest trading partner. In 2018, the trade volume between the two countries continued to grow, reaching a total of US\$21.272 billion, an increase of $18 \%$ year-onyear.[4] In order to promote economic cooperation between the two countries, the two sides have started specific cooperation around the biotechnology and pharmaceutical research and development and launched the "smart city plan", thereby transforming and improving urban infrastructure, improving the quality of life and the happiness index of residents. Russia-Korea trade hit a new high. The situation on the peninsula in 2018 was generally stable. With the improvement of the bilateral relations, Russia-Korea relations have shown a benign development trend and achieved remarkable results in economic cooperation. In 2017, while the trade volume between the two countries was US\$19 billion, there is an increase of $28.85 \%$ in the same period in 2018 up to US $\$ 24.8$ billion.[5] In June 2018, during President Moon Jaein's visit to Russia, he signed a declaration of the two countries' free trade zone with the Eurasian Economic Union, which enabled Russia-Korea trade to obtain many guarantees from policy formulation to tax and fee concessions, and further activated the economic cooperation between the two countries. RussiaMongolia trade has steadily improved. Russia has been Mongolia's second largest trading partner in the past few years, second only to China. In 2018, the trade volume between Russia and Mongolia was US $\$ 164.9$ million, an increase of $20.6 \%$ from 2017 . In 2018, the Mongolian railway capacity reached a record high of 25.7 million tons, an increase of $13 \%$ year-onyear [6], which is largely due to the "Ulaanbaatar Railway Company" jointly constructed by Russia and Mongolia.

Third, further strengthen national security cooperation with Northeast Asia. China-Russia military security cooperation is an important manifestation of high-level strategic mutual trust between the two countries. In 2018, the two armies held the "Marine Joint-2018" military exercise, and the Chinese army participated in the "Oriental-2018" strategic exercise held by Russia for the first time, which marked that the two countries have reached a new level of military cooperation in line with the unprecedented political mutual trust.[7] In September 2018, the United States announced that it would impose sanctions on China on the grounds that China's purchase of Su-35 fighter jets and S-400 air defense missiles from Russia violated the "Act on Sanctions against American Adversaries". [8] China's response to this is: China and Russia will not weaken military cooperation, and will confirm the China-Russia comprehensive strategic "side by side, back to back" partnership with practical actions in the new era.

In addition to China, Russia has also promoted security cooperation with other Northeast Asian countries. With Japan: With the efforts of the leaders of the two countries, Russia and Japan have frequent dialogues in the field of diplomacy and security. In March, in order to promote the negotiation process of territorial issues, Russian Foreign Minister Lavrov paid a working visit to Japan [9]. In July 2018, Russia and Japan held a "2+2 Diplomacy and Security" dialogue to release a strong signal of trust and understanding. With Mongolia: Russia-Mongolia relations have a long history. Military cooperation is a traditional field of cooperation between the two countries and is being strengthened year by year. On October 18, 2018, the Russian Defense Minister visited Mongolia and negotiated with Mongolian Defense Minister Namakin Enkhbold in Ulaanbaatar and signed a military cooperation agreement between Russia and Mongolia. The agreement was aimed to develop military cooperation between Mongolia and Russia, especially in the fields of military education, medical science, humanitarianism, and joint military exercises, and aimed to train Mongolian experts for the local army [10].

\section{ANALYSIS OF THE NEGATIVE FACTORS OF RUSSIA'S DEEPENING COOPERATION IN NORTHEAST ASIA}

First, Russia's economic growth is sluggish, making it more difficult to attract foreign investment. In 2018, the Russian economy progressed steadily under the hostile external conditions, maintaining and consolidating the development trend with the total external debt reduced by more than 60 billion U.S. dollars. This achievement was made under such unfavorable conditions as the continuous expansion of external sanctions against Russia, the international oil price fluctuations, trade tensions, and world economic 
slowdown. But we also see that in order to ensure that Russia's economic growth rate would keep up with the world's average level, it should receive an additional investment of 5 trillion rubles (about 86.8 billion US dollars) every year [11]. Russia couldn't afford this on its own. Secondly, the extended economic sanctions against Russia to 2024 further cut off its financing capital chain, increasing the difficulty of attracting foreign capital. And Russia's foreign financial cooperation would be in a bitter struggle. Third, with the slowdown of global economic growth, the spread of anti-globalization and trade protectionism, the demand for crude oil in 2019 is unlikely to be optimistic and the future of oil prices is too dim to increase significantly, which will greatly limit the purchasing power of Russia and its development of economic and trade cooperation with neighboring countries.

Second, international crude oil prices fall, increasing downward pressure on the economy. In 2020, Russia suffered the sharp fall of the crude oil price on the world market falling from US\$65 per barrel at the beginning of the year to US $\$ 30$ per barrel after the country withdrew from the "OPEC+" agreement and then was inflicted by the resulting turmoil of world financial markets [12], including the country's largest trading partner, the European financial market, worsening Russia's economy which relied heavily on raw material exports. The Russian Ministry of Finance had previously made a disturbing prediction: For one dollar drop of international oil prices, Russia's fiscal revenue would be reduced by 70 billion rubles (about 1.5 billion US dollars) [13]. This shows that the decline in international oil prices will directly cut Russia's budget revenue, resulting in an increase in the deficit and the inability to execute budget projects, which in turn exacerbated the downward pressure on the economy.

Third, the extension of sanctions makes it difficult for Russia-US relations to change in the short term. The current international upheavals are affecting all countries in the world, making no exception to Russia. In particular, the sanctions against Russia imposed by Europe and U.S. would last to 2024, and the relationship between them is unlikely to improve significantly in the short term. At the same time, Russia is also struggling to cope in the Asia-Pacific region. First of all, in the process of resolving the Korean Peninsula issue, Russia is not as important as expected, being weakened all the time. The United States will not cancel the deployment of "THAAD" on the Korean Peninsula and Japan sticks with developing its anti-missile and defense systems. Second, the
Russia's deepening of cooperation with major countries in Northeast Asia is also full of obstacles.

\section{CONCLUSIONS}

First, political relations between Russia and northeast Asian countries are moving towards friendship. In 2021, Russia is facing a complex and ever-changing world, and the international order is in a stage of deep structural adjustment. Russia has a number of important strategic options such as strengthening interaction with the Asia-Pacific region, offsetting losses caused by sanctions to the greatest extent, playing a constructive role on international issues, promoting conflict resolution, and enhancing Russia's international influence and status as a major power. In the future, Russia-US relations will continue to be worse due to sanctions, information warfare, NATO and other issues. In order to break through the Western barrier and fight for a greater voice in Northeast Asia, Russia will shift its strategic focus to the east and actively "look east" to seize opportunities. Internally, Russia will further clarify the exportoriented economic development model of the Far East for the Asia-Pacific region. Externally, Russia will promote the construction of the Greater Eurasian Partnership and more actively develop political and economic exchanges with Northeast Asian countries [14].

Second, economic and trade cooperation with Northeast Asian countries is gradually improved. It is very important for Russia to develop economic and trade cooperation with Northeast Asian countries. First of all, the sanctions of Western countries have worsened Russia's economy. To maintain national security and maintain its status on the international stage, Russia must strengthen cooperation with Northeast Asian countries, find technology and markets in the East, and create growth points for domestic economic development. In the 21 st century, globalization and the evolution of major powers have brought new opportunities for the accelerated development of the Asia-Pacific region. Russia must fully grasp the advantages of economic, capital, market, labor, technology and regional security in Northeast Asia and consolidate the achieved geopolitical benefits. Secondly, the development of the Russian Far East region is inseparable from the technical and financial support of Northeast Asian countries. If China, Japan, and South Korea would be engaged on Russia's Far East development with funds and technology, the Far East should be integrated into the Asia-Pacific economic circle in time [15]. 
"The Strategy for the Development of The Russian Information Society (2017-2030)" released in 2017 has repeatedly mentioned the need to improve the international competitiveness of Russian high-tech companies. In fact, since 1998, Russia's economic growth has not been driven by high-tech production. According to the data from the Russian Center for Scientific Research and Statistics, from 2001 to 2007, the number of staff engaged in scientific research and design in Russia decreased by $9.8 \%$, and the number of scientific research units fell back from 2008 to the level of 2004. The average index of enterprise innovation activity was relatively low, and there was a shortage of innovative talents. Therefore, Russia is committed to achieving breakthroughs and innovations in high-tech fields such as wireless communication technology, blockchain, quantum technology and nanotechnology on the basis of developing advantageous fields such as aviation, missile technology and nuclear energy, and hopes to cooperate with northeast Asian countries that have made some achievements in the field of digitalization.

Third, Russia continues to intervene in the DPRK nuclear issue and expand its influence in Northeast Asia. As a legacy of the Cold War, the Peninsula issue not only has a strong historical origin, but also involves political games among major powers. At present, whether a country has a say on the peninsula issue or whether it has influence over the DPRK directly reflects a country's political voice, decisionmaking power, and national governance capacity in Northeast Asia. It is also the main indicator for the influence of a country's international power. In view of the important geopolitical value of the Korean peninsula, it is always an important part of Russia's Northeast Asian strategy to attach importance to developing bilateral relations with North Korea and maintain influence on the peninsula issue to seek geopolitical interests. As a result, Russia continues its intervention strategy on Korean peninsula affairs. In addition, as an active participant in resuming the SixParty Talks, Russia is very willing to play an important role in resolving the North Korean nuclear issue, employing the "Talks" to deepen relations with Japan and South Korea, and to avoid over-reliance on China in its 'eastward shift' policy.

\section{REFERENCES}

[1] Li Yonghui, Russia's Asia-Pacific Diplomacy in 2018-Also on the Relationship between the IndoPacific Strategy and the Strategic Concept of the Greater Eurasian Partnership. Russian Journal 4 (2019) 45-48.
[2] Li Kuiwen, Deepen cooperation, build consensus and join hands to promote smooth trade in the China-Mongolia-Russia Economic Corridor. Northern Economy 7 (2019) 20-23.

[3] Feng Xiaoling, Jiang Shanshan. Analysis of the cooperation and development of the ChinaMongolia-Russia Economic Corridor under the "One Belt and One Road" Initiative. Northeast Asian Economic Research 4 (2019) 31-32. DOI: https://doi.org/ 10.19643/j.cnki.naer.2019.04.002

[4] E Xiaomei, Problems and countermeasures in the construction of the "five links" of the ChinaMongolia-Russia Economic Corridor. Inner Mongolia Social Sciences 5 (2017) 208. DOI: https://doi.org/ 10.14137/j.cnki.issn10035281.2017.05.032

[5] Chang Bin, Thoughts on the regional cooperation between China and Russia. Siberian Studies 4 (2014) 20-24.

[6] Yang Lihua, Dong Zhiyong, Economic constraints and advancing paths in the construction of ChinaMongolia-Russia Free Trade Zone. Journal of the Central Party School of the Communist Party of China 4 (2018) 124. DOI: https://doi.org/ 10.14119/j.cnki.zgxb.2018.04.015

[7] Chang Bin, Thoughts on regional cooperation between China and Russia. Siberian Studies 4 (2014) 20-24

[8] Cai Yunzhe, Sino-Russian Cooperation in Pandemic Narrative Game. Russian Journal 5 (2020) 25-28.

[9] Jiang Jing, Problems and Suggestions for Deepening Local Pragmatic Cooperation under the Background of Sino-Russian Relations in the New Era. Journal of Northeast Asia 12 (2018) 4044.

[10] Li Yongquan, Eurasian Geopolitical Situation and Great Power Game. Russian Studies 4 (2018) 1015.

[11] Li Kuiwen, Deepen cooperation, build consensus and join hands to promote smooth trade in the China-Mongolia-Russia Economic Corridor. Northern Economy 7 (2019) 21.

[12] Zhao Mingwen, Sino-Russian Relations: A Comprehensive Strategic Partnership in the New Era. Research on International Relations 4 (2017) 15-18. 
[13] Li Yang, Observing the Status Quo and Prospects of Russian Economic Growth from Historical Mirror Images. Xinjiang Finance and Economics 5 (2019) 26-31.

[14] Wang Xiaoquan, Analysis on the Law of the China-US-Russia Triangle. Russian. Eastern Europe and Central Asia Studies 6 (2017) 5-11.

[15] Wang Weiguang, Understand and develop the comprehensive strategic partnership of cooperation between China and Russia in the new era from a strategic perspective. World Socialism Studies 5 (2018) 30-39. 